Krystyna Michałowska*, Tomasz Nałęcz ${ }^{* *}$, Ewa Głowienka-Mikrut***, Sławomir Mikrut***, Jakub Garczarek

\title{
The Use of Land Surveying in the Process of Managing Mineral Deposits ${ }^{* * * *}$
}

\section{Introduction}

Mining activities related to the exploitation of common minerals (sand, gravel) that are generally extracted by means of open pit methods are inherently connected with performing land surveys. Those surveys provide basis for reporting and settlements required under license regulations that govern minerals mining [3,6]. Land surveys are utilized mainly at the stage of the deposit exploitation. They also are an extremely essential element of works upon the closure of mining, that is at the phase of land reclamation planning. It is of vital significance to the entrepreneur to correctly determine the volume of the depleted part of the deposit as it provides grounds for financial settlements with relevant agencies or authorities. However, classic methods [10] that are most often applied may bring about considerable errors, which in turn result in making payments that are disproportionate to the actual output. This paper presents an alternative way of using topographic maps in the process of determining the volume of minerals extracted from the deposit. The measurement methods referenced herein may also become applicable for the optimization of planning and implementation of land reclamation works consisting in the reduction of inclination of slopes originating as a result of mining activities.

\section{Location and Discription of the Study Area}

The project area is located in the commune of Moryń, the Zachodniopomorskie province (Poland). The area selected for conducting analyses and making

* University of Agriculture in Krakow, Poland

** Polish Geological Institute - National Research Institute, Warsaw, Poland

*** AGH University of Science and Technology, Faculty of Mining Surveying and Environmental Engineering, Krakow, Poland

**** This paper has been prepared within the scope of the AGH UST statutory research no. 11.11.150.949 
calculations was the depleted part of the "Skotnica" natural mineral deposit (Fig. 1). The major part of soil above the deposit was agriculturally developed (class V and VI soils) [8]. The density of formations within the deposit ranges from $1.7 \mathrm{~m}$ to $18.5 \mathrm{~m}$, and the surface area of the deposit amounts to ca. 41 ha. The mining license, granted to Lafarge Beton Towarowy Sp. z o.o., expired in the beginning of 2013.

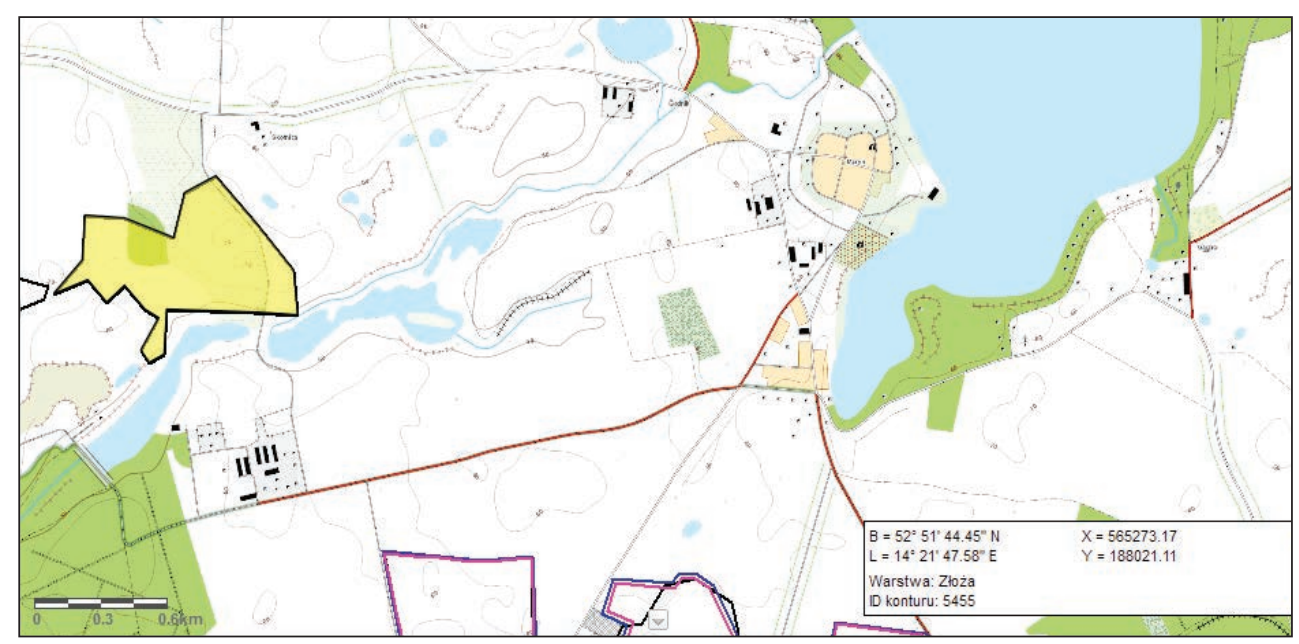

Fig. 1. Location of the Skotnica deposit

Source: MIDAS database, www.pgi.gov.pl

Basic data were obtained from the current topographic map of the Skotnica deposit area, scale $1: 2000$ (valid as at 31 December 2011).

\section{Legal Bases}

The Act of 9 June 2011 - The Geological and Mining Law (Journal of Laws, No. 163, Item 981) [9] imposes, as regards mining activities, an obligation on entrepreneurs to maintain land survey and geological documentation, and to keep records of the deposit resources (Art. 101.1 and Art. 116.1). The same act also obligates the entrepreneur to protect (improve) natural environment (Art. 129.1). In the event that a mining plant is liquidated, the entrepreneur is obligated to, among other things, secure the excavation pit.

In both aforementioned cases the implementation of tasks imposed by the legislator involves the utilization of surveying methods for the preparation of a map, based on which the necessary calculations can be made. 


\section{Classic Measurement Methods}

The determination of the mining output volume, and, through that, the determination of the deposit resources is nothing but calculating the difference in excavation pit volumes in a given time (e.g. in the settlement period) since tonnage depends on the mineral density. The most common method of calculating the volume of excavated material is to calculate the surface area of the excavation pit, separately for the top and bottom edges of slopes, and then to multiply the average surface area by the density of the depleted deposit [10]. An analogous method is to draw into a topographic map the so-called theoretical contour of the excavation pit, which is a line drawn at the half of the slopes' height. Also in that case the calculation of the output volumes comes down to multiplying of that contour area by the density of the depleted deposit. However, both referenced methods may be encumbered with gross errors.

\section{Model of the Excavation Pit Surface}

There were 246 points obtained for the existing excavation pit, which border it. Those points constitute en external contour of the bottom surface that limits the volume of depleted resources. The points were obtained based on topographic map in Mikromap software. The next stage was the creation of a grid of squares made of points bordering the excavation pit. It has been decided that, from among available methods of interpolation, the best results would be obtained by means of the kriging interpolation method. In order to eliminate rough errors originating from manual extracting points from the map, the excavation pit surface (without external heaps) was subjected to spatial visualization in Surfer software (Fig. 2).

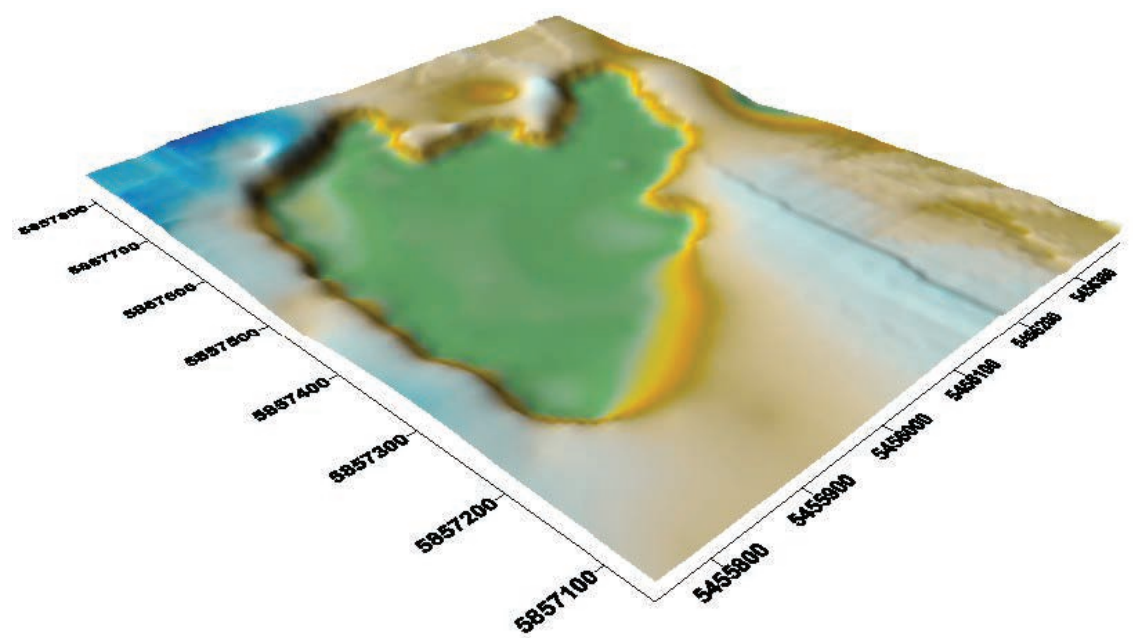

Fig. 2. Spatial model of the excavation pit surface as generated in Surfer software 
The excavation pit as defined at this stage constitutes the bottom surface limiting the volume of earth masses that are the object of calculations. The top surface was obtained based on 10 drilling holes located within the excavation pit, which outline the pit roof.

For both the bottom, and the top surfaces there were auxiliary points introduced to mark the outline surface so that to make it unambiguous in volume calculations. As a result, both the sets of data for bottom and top surfaces have additional points, which unambiguously outline the contour of the examined area. Part of those points are at the same time points of the top surface (roof), so they will continue to be named as relating to the "outline" and not to the "roof."

Analogically, just like in the case of the excavation pit surface, also for the roof a grid of squares was produced by means of the kriging interpolation method, and was subjected to spatial visualization in Surfer software to eliminate rough errors (Fig. 3).

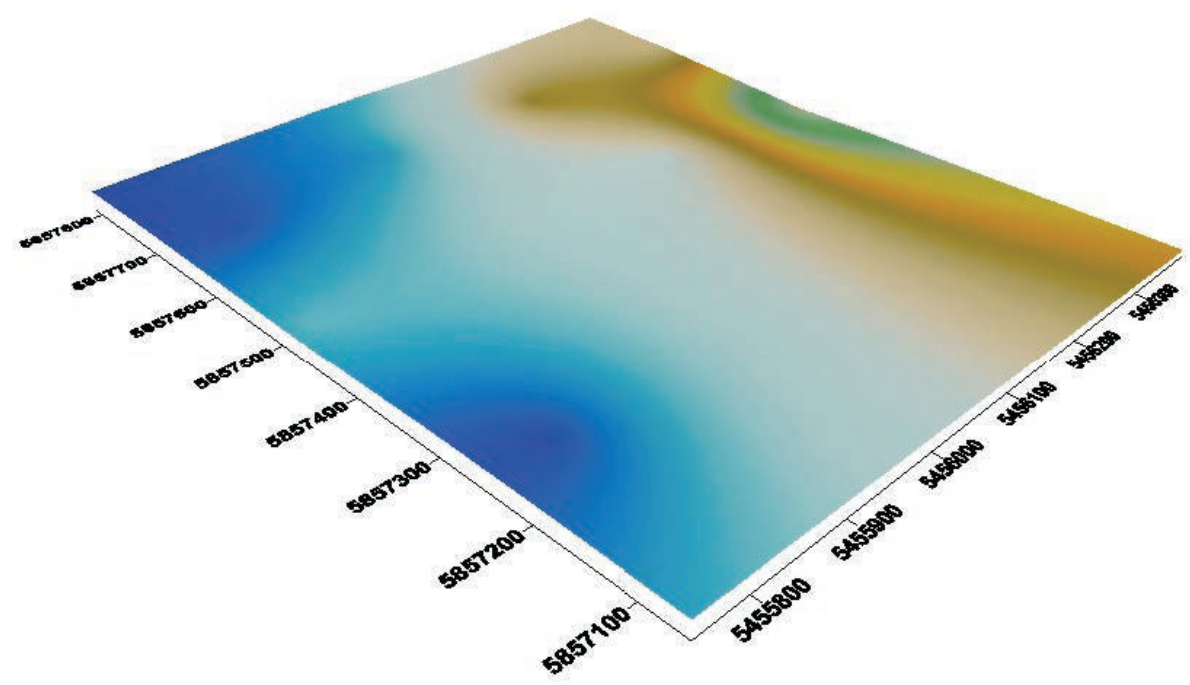

Fig. 3. Spatial model of the excavation pit roof as generated in Surfer software

The surface of the excavation pit roof was determined at the documentation stage, i.e. prior to the commencement of mining activities. The bottom surface represents the current state of the excavation pit. It is therefore possible to define both surfaces, between which total volume of the aggregate (that has so far been extracted is) confined. Using grids of squares of both surfaces, calculation of resources of the depleted deposit was made in Surfer software.

Based on obtained results, the volume of the depleted part of the Skotnica deposit resources was calculated. It amounted to $1,686,750 \mathrm{~m}^{3}$. The difference in 
relation to the quantity calculated by means of a traditional method $\left(1,688,604 \mathrm{~m}^{3}\right)$ equals $0.1 \%$ and amounts to $1,854 \mathrm{~m}^{3}$.

\section{Land Reclamation of the Mining Pit}

Another example of the use of land surveying in the process of managing mineral deposits is planning and optimisation of the land reclamation process. Upon the termination of mining activities, the entrepreneur is obligated to restore the land usable properties. The most common methods of land reclamation include either water, or forest reclamation $[1,2]$. One of vital elements of reclamation works is proper shaping of pit slopes to prevent landslides, and to get the slope surface stabilization effect $[4,5]$.

Manual outlining of edges of newly designed slopes consists in parallel drawing of lines from the current slope edges, with spacing maintained in accordance with the tangent function [10], i.e. equalling the slope height divided by the designed angle tangent. In the case of a single slope, the value of the laid off angle should be the same for the top and for the bottom edges of the slope. Such a symmetric arrangement is economically justified and ensures maintaining a correct balance of earth masses. In order to make the above process automatic, one should have points that precisely determine the given object and are ordered in a way, which makes it possible to make calculations. In the above set, one can differentiate pairs of points situated on a single line, which is perpendicular to the slope span, out of which one point is situated on the bottom, and the other on the top edge.

Further calculations employed a text file, which included, in successive columns and separated by space characters, the point names and $X, Y, Z$ coordinates. Since the points are arranged in pairs (in relation to the bottom and top slope edges), it is possible to perform calculations to determine edges of a newly designed slope.

In the next stage, the text file with points obtained from the map was imported to MS Excel, where coordinates of points determining the designed slope edges were automatically calculated. Next, coordinates of the midpoint of the section determined by pairs of points $(X S, Y S)$ were calculated. The slope plane should be intersected in the half of its width, and so points with coordinates XS, YS will outline an edge, from which half of the spacing of newly designed slope edges was laid off. Also height difference for each pair of points was determined, and spacing of the designed slope, based on the tangent function:

$$
D=\frac{H}{\operatorname{tg} 20^{\circ}}
$$

where:

$$
\begin{aligned}
& D \text { - distance, } \\
& H \text { - height. }
\end{aligned}
$$


The solving of the problem is nothing but calculating new coordinates, which will emerge as a result of laying off half of the distance D towards bottom and top slope edges, following the direction established by the pair of points. In order to complete that assumption, one must calculate the azimuth indicated by the pair of points and $D X$ and $D Y$ increments, by which the original coordinates will be changed. $D X$ and $D Y$, which are coordinate increments of the pair of points, were calculated, as well as the tangent of quadrantal bearing, which was determined based on said increments $(D X: D X)$. Afterwards, the value of quadrantal bearing was obtained, based on arc $t g$ function. Calculations that have been made so far make it possible to obtain the value of azimuth (in radians) determined by pairs of points (and thus by pairs of designed points), and to calculate increments for pairs of points that determine new slope edges $(D X, D Y)$. In the last stage of calculations coordinates of points that determine slope edges were defined (slope inclination $20^{\circ}$ as per assumptions). On the basis of the presented calculation algorithm, coordinates of resultant points were established, which will be used to construct a model of the designed slope.

Similar calculations have to be made for all selected objects within the excavation pit. In order to make that process automatic, proper macros were prepared to enable quick performance of calculations taking into consideration any number of input objects.

The resultant text file has a structure, which makes it possible to immediately import points to Mikromapa program. After data have been imported, it is necessary to draw new slope edges based on new points. In the event of a large volume of data, the job can be made considerably easier by using a tool to draw the line following the numbers of points.

In the next stage of work, spatial model of the current and designed states was produced. To eliminate rough errors originating from manual entering of height values in the initial stage of this job, a spatial model of the existing slope and of the designed slope was presented, using the Surfer program. Similarly, like in the case of visualization of the whole excavation pit, two grids of squares were constructed for the presented slopes: first one for the existing slope, and second one for the designed slope. Since the elementary slope has a primitive surface, the grid model was generated with the use of a linear interpolation method, with division into irregular grid of triangles.

A significant element in these works is the defining of earth mass volumes to be relocated for the obtaining of the intended result since it offers a possibility of project cost estimation to be made by the investor. Calculations of earth mass volume for the example under consideration were also made in the Surfer program. To perform the calculation, it is necessary to construct a grid of squares for the bottom and top surfaces that confine the given earth volume. The bottom surface is determined by points, based on which the designed slope was drawn (the resultant points). The top surface includes both the aforementioned points, and original points, obtained from the existing state. The top limit is therefore a set of points from both text files. The combined content of files served as a basis for the creation of a set with another grid of squares. 
As a result of calculations performed, coordinates of points were obtained, which can be presented on a topographic map. Based on them, the surfaces of the designed slope will be determined. Figure 4 shows the designed slope and the resultant points, as well as spatial model of the existing and the designed slope.

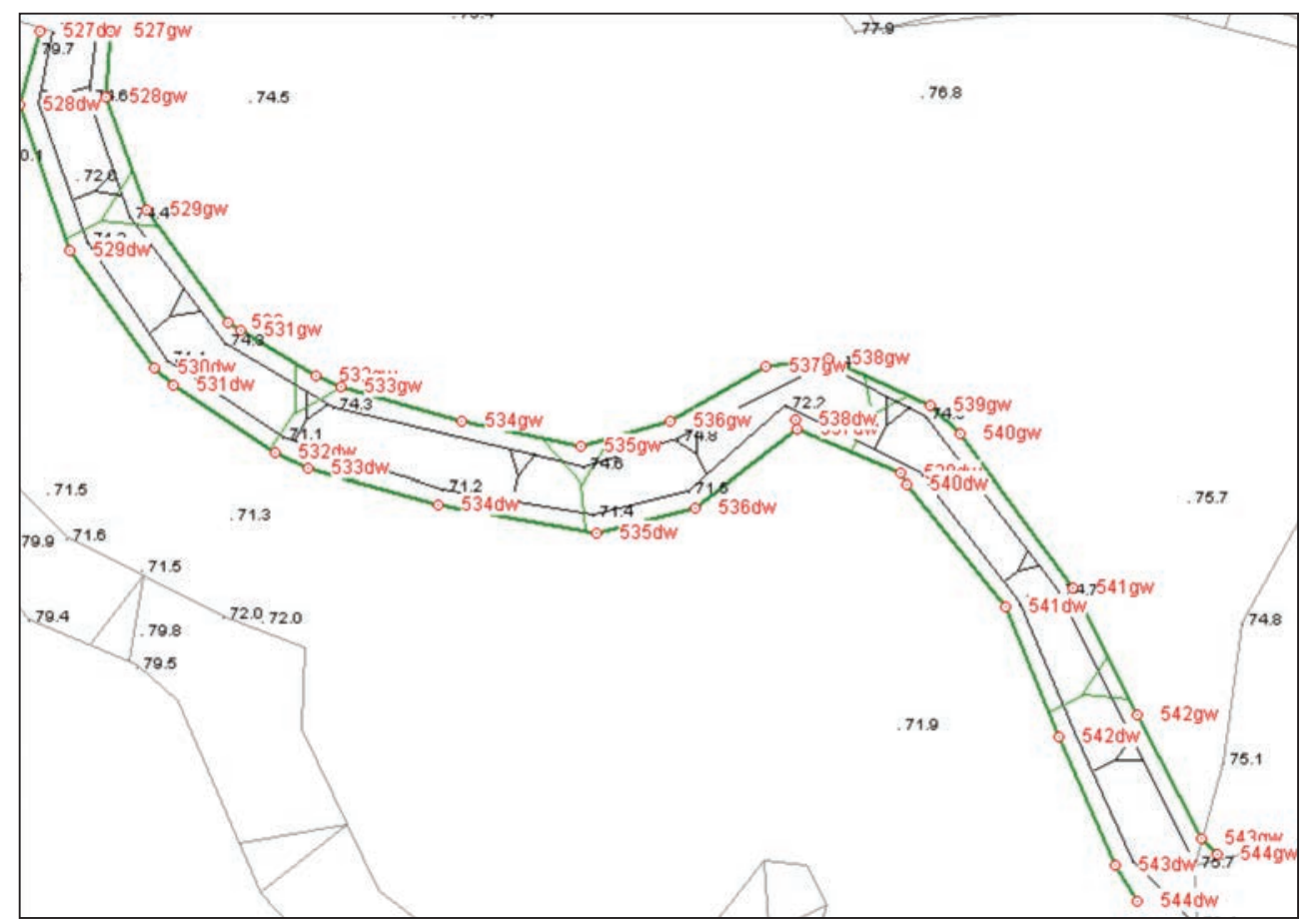

Fig. 4. Fragment of the map showing the designed slope (green colour) and resultant points (red colour)

Using the above-presented methods, the slope edge course was determined. The slope inclination angle will be $20^{\circ}$. At the same time economic conditions for the designed works were considered since difference between the volume of earth masses necessary to truncate the slope $\left(217 \mathrm{~m}^{3}\right)$ and that necessary to build it up $\left(206 \mathrm{~m}^{3}\right)$ is $5 \%$, which proves a correct implementation of theoretical assumptions related to the earth mass balance. During land reclamation works $217 \mathrm{~m}^{3}$ of earth masses will be pushed away and shovelled, and $95 \%$ of that volume, i.e. $206 \mathrm{~m}^{3}$ will be used to build up the bottom part of the slope, so $11 \mathrm{~m}^{3}$ will become an unnecessary surplus. In practice, tens or even hundreds of thousands of tons of earth masses are relocated, so this is a negligible quantity.

The methods of calculation as presented herein may also be applied for works related to reducing the inclination of mounds and dump faces. In addition to reducing 
steeply inclined surfaces of the mining pit, it is also necessary to calculate the volume of floral humus heaps that originated as a result of the previous removal of the pit overlay. Humus is often heaped and stored since it constitutes a perfect material to be spread on the surface of the no-longer operating excavation pit to afforest it later.

\section{Conclusions}

The calculation methods presented in this paper, as well as modelling of mining pit surfaces, constitute practical examples of the utilization of land surveying techniques in the process of managing mineral deposits. Considering thousands of minor pits excavating common minerals in the scale of the entire country, undertaking of the indicated action may lead to considerable savings. Correct calculation of the volume of depleted part of the deposit provides grounds for reporting, and, consequently, for paying licence fees which, thanks to precise calculations, may yield savings. Savings can also be gained from an efficient planning of land reclamation works, where volumes of earth masses necessary for the correct shaping of postmining slopes need to be defined. The projection of exact quantities of earth, made possible due to the application of modelling methods, enables business entities to plan and asses costs of purchasing additional soil, necessary to shape slopes. This also means savings to the entrepreneur, both in terms of finances, and time.

The results of completed works and analyses prove that it is worth using landsurveying methods when calculating resources during geological projects, especially when ready databases are available. This will allow to complete the task in a shorter time, and to eliminate errors that are likely to appear in the preparation of data for calculations made with the classic method.

Methods presented in this paper made it possible to precisely determine the quantities of depleted minerals, and to mark out within the pit area new edges of the designed slope or a dumping ground, all that in compliance with technical assumptions and taking into account the economic conditions.

\section{References}

[1] Dobak P., Drągowski A., Frankowski Z., Frolik A., Kaczyński R., Kotyrba A., Pinińska J., Rybicki S., Woźniak H.: Zasady dokumentowania warunków geologicznych dla celów likwidacji kopalń. Ministerstwo Środowiska, Warszawa 2009.

[2] Gworek B. (red.): Technologie rekultywacji gleb. Monografia. Dział Wydawnictw IOŚ, Warszawa 2004.

[3] Maj J.: Procedura udzielania koncesji na wydobywanie kopalin przez starostę. Kopaliny. Czasopismo Górnictwa Odkrywkowego, nr 78(5/2012), 2012, pp. 2-8. 
[4] Modern Open Pits. International Mining, [on-line:] http://www.im-mining. com/2013/09/02/modern-open-pits [access: December 2013].

[5] Rose N.D., Hungr O.: Forecasting potential slope failure in open pit mains - contingency planning and remediation. International Journal of Rock Mechanics and Mining Sciences, vol. 44, 2007, pp. 308-320.

[6] Rozporzadzenie Ministra Środowiska z dnia 20 grudnia 2011 r. w sprawie szczegółowych wymagań dotyczacych projektów robót geologicznych, w tym robót, których wykonywanie wymaga uzyskania koncesji. Dz. U. nr 288, poz. 1686.

[7] Sitek Z.: Fotogrametria inżynierska. Skrypty Uczelniane AGH, Kraków 1979.

[8] Sokołowski J.: Geologia regionalna i złożowa Polski. Wydawnictwa Geologiczne, Warszawa 1990.

[9] Ustawa z dnia 9 czerwca 2011 r. - Prawo geologiczne i górnicze. Dz. U. nr 163, poz. 981.

[10] Zając Cz.: Miernictwo górnicze. "Śląsk” Wydawnictwo Naukowe, Katowice 2002. 